\title{
Determinants of Attitudes Toward Muslim Students Among Flemish Teachers: A Research Note
}

\author{
ORHAN AGIRDAG \\ Department of Sociology \\ Ghent University
}

\author{
MIEKE VAN HOUTTE \\ Department of Sociology \\ Ghent University
}

\author{
PATRICK LOOBUYCK \\ Department of Philosophy \\ University of Antwerp
}

\begin{abstract}
Muslims are now the second largest religious group in almost all Western countries and a large majority of Muslim citizens are children who attend schools. However teachers' attitudes regarding the education of Muslim students are largely ignored by educational researchers. In this study, we investigate the determinants of teachers' attitudes among Flemish (Belgian) teachers $(N=620)$. Regression analysis has revealed that female teachers, Muslim teachers, younger teachers, and teachers with a four-year college degree have significantly more positive attitudes. Most interestingly, we found that teachers working in schools that enroll a larger share of Muslim students (greater than 50 percent) have more negative attitudes toward Muslim students than other teachers. The implications of these findings for educational policy are discussed.
\end{abstract}

Keywords: Muslims, Islamophobia, segregation, Flanders.

\section{INTRODUCTION}

The number of Western citizens who describe themselves as Muslim is increasing and Muslims are now the second largest religious group in almost all European countries (Hunter 2002; Niyozov and Pluim 2009). However, this demographic trend is a source of concern for many policymakers (Norris and Inglehart 2009; Schinkel and Van Houdt 2010). In West Europe a large majority of Muslim citizens are children and the challenges regarding the education of Muslim students have received much scholarly attention. These studies examine academic (under)achievement and the effectiveness of Islamic schools (e.g., Agirdag, Hermans, and Van Houtte 2011; Driessen and Van der Slik 2001; Driessen 2002; Zine 2008). However, as noted by Niyozov and Pluim (2009), only a few studies have paid attention to teachers and their attitudes toward the education of Muslim students.

In many European countries, the educational achievement of Muslim students originating from North Africa, the Middle-East, Turkey, and Asia is lower than that of native European students (see Agirdag, Van Houtte, and Van Avermaet 2011; Dronkers and van derVelden 2010). Recent empirical studies have found that prejudiced teacher attitudes and expectations enlarge the achievement gap between ethnic minority and majority pupils (see McKown and Weinstein 2008; van den Bergh et al. 2010). Despite a literature that points to the importance of teachers and

Acknowledgments: This study was performed while being a recipient of a Fellowship of the Belgian American Educational Foundation and a Fellowship of the Fulbright Commission Belgium. Thanks are due to Professor Emile Boulpaep and Ms. Margaret Nicholson for their support.

Correspondence should be addressed to Orhan Agirdag, Department of Sociology, Ghent University, Korte Meer 5, 9000 Gent, Belgium. E-mail: orhan.agirdag@gmail.com 
their attitudes for educational achievement (Rosenthal and Jacobson 1968), teachers' attitudes toward the ever growing Muslim student populations in Western countries remains understudied.

Research that includes teachers' perspectives has focused specifically on teachers in Islamic schools (e.g., Selby 1992; Zine 2008), but more than 90 percent of Western Muslims attend public schools (Niyozov and Pluim 2009). The few studies about teachers in regular schools report mixed results. While some report that many teachers display Islamophobic attitudes (e.g., Merry 2005; Richardson 2004; Zine 2001), others find that teachers demonstrate positive and committed attitudes toward Muslims and Islam (Abbas 2002; Haque 2001). These studies are mostly based on ethnographic research designs; virtually no research has investigated the determinants of teacher attitudes. Consequently, little is known about the influence of teacher characteristics (e.g., gender, religion, or age) and school characteristics (e.g., school type or share of Muslims in schools) on teachers' attitudes regarding Muslim students. Knowing whether there is an influence may be useful to policymakers or educational administrations. The aim of this study is to examine the determinants of teachers' attitudes toward Muslim students in Flanders, which is the northern part of Belgium.

\section{Literature Background and Hypotheses}

Previous studies on teachers' attitudes toward Muslim pupils yielded mixed results for different countries and regions (for a brief review, see Niyozov and Pluim 2009). Zine (2001) provided an ethnographic analysis of the schooling experiences of Muslim youth in Canada, noting problematic relationships between students and teachers resulting from the Islamophobic attitudes of teachers. Similar arguments are made by Richardson (2004) in the United Kingdom and by Merry (2005) in Belgium. Nevertheless, disconfirming findings are made by Haque (2001) and Abbas (2002). In a study of Australian teachers, Haque (2001) found that a majority of teachers demonstrated positive attitudes toward Muslims and Islam and strongly supported the idea of multicultural coexistence. In Birmingham, Abbas (2002) suggested that teachers were on the whole positive about the cultural and social "baggage" that Muslim students took to the school.

Teachers' positive or negative attitudes toward Muslim students might be related to a set of background and demographic factors. The teacher's religious background may be an important influence. According to social identity theory (Tajfel 1981) individuals tend to categorize themselves in so-called in-groups and out-groups and the value that they attach to a certain group (e.g., Muslim students) is dependent on whether the group belongs to the in-group or the out-group. In-groups are more likely to be evaluated positively (i.e., in-group favoritism) and out-groups negatively (out-group derogation). As such, it can be expected that Muslim teachers will hold more positive attitudes toward Muslim students than other teachers.

Second, educational level might result in a better understanding of various religions, including Islam (see Ipgrave, Miller, and Hopkins 2010). Indeed, previous studies have found more educated people have more positive attitudes toward Muslims and are less Islamophobic (Bevelander and Otterbeck 2010; Fetzer and Soper 2003; Heitmeyer and Zick 2004; Savelkoul et al. 2010). As such, a higher educational degree can be expected to generate more positive attitudes among teachers.

Third, age, and consequently, years of teaching experience might have an effect. Previous studies have found more negative attitudes among older respondents (Dunn, Klocker, and Salabay 2007; Heitmeyer and Zick 2004). Older teachers will be more negative toward Muslim students and their religion. In the last decade teacher education programs in Flanders have included multicultural/multifaith education courses and more attention is being paid to religious diversity.

Finally, gender might be related to teacher attitudes as previous studies reveal that women hold less negative attitudes toward Muslims than men do (see Bevelander and Otterbeck 2010; Heitmeyer and Zick 2004), although mixed findings are provided by Fetzer and Soper (2003). For instance, Fetzer and Soper (2003) found that French females were more negative toward 
state accommodation of Muslim religious practices than French males, while in Germany, the opposite was true.

While teachers have general conceptions about teaching and their students, they are inclined to adjust these conceptions to the contextual factors of the school (Finn 1972; Van Houtte 2011). First, the percent of Muslim students enrolled in the school where a teacher works might have an influence on his or her attitudes toward Muslims. Drawing upon the intergroup contact theory (Allport 1954), a higher share of Muslim students at school can be expected to positively affect teachers attitudes as a consequence of increasing contact between teachers and Muslim students. However, four conditions need to be fulfilled for the intergroup contact to be effective: (1) the contacts must occur in an equal status, (2) the groups must have shared goals, (3) groups must cooperate to achieve the goals, and (4) the authorities must support interaction initiatives between the groups. In particular, condition one is hardly met in the (Flemish) educational situation: teachers do not have the same status as (Muslim) students (see Agirdag et al. 2011). Therefore, a greater share of Muslim students in the school might be unrelated or may increase negative attitudes toward Muslim students. From a group threat theory perspective (Blalock 1967) an increasing number of out-group members in a given context might be perceived as a threat by the native group and cause feelings of symbolic dominance. Consequently, negative attitudes toward the out-group (e.g., Muslim students) might flourish.

A second structural characteristic is school sector. In Belgium, public (state) schools are in the minority, especially in Flanders. Almost 63 percent of all Flemish pupils are enrolled in nonpublic primary schools and 75 percent are enrolled in nonpublic secondary schools. Approximately 99 percent of these nonpublic schools are Catholic. According to article 24 of the Belgian Constitution, public schools are obliged to offer religious education in the recognized religions and in nonconfessional ethics (Loobuyck and Franken 2011). As a result, all public schools organize Islam courses for their Muslim students. In the Catholic schools, all the students, including Muslim students, follow the course of Roman Catholicism. Nondenominational state schools explicitly encourage "active pluralism," while in Catholic schools the pedagogical project is embedded within the Christian tradition. Christianity still has a priority position as a point of reference. However, much has been done to increase the dialogue between Christian and non-Christian religious traditions. No a priori hypothesis about the influence of school sector (public or nonpublic) on the attitudes of the teachers toward Muslim students is proposed. Finally, the educational level of the school may also be related to teachers' attitudes. However, regarding the effects of educational level, no a priori hypothesis is proposed.

\section{Methods}

\section{Research Design and Sample}

Data were gathered during the 2008-2009 academic year, from 620 Belgian (Flemish) teachers as part of a larger project in five European countries on Muslim student integration (see Sharpes et al. 2010). A questionnaire on teachers' attitudes toward Muslim students was designed using qualitative interviews with teachers and headmasters. This questionnaire was translated into Dutch and adapted to the Flemish educational system to survey Belgian (Flemish) teachers. The respondents were selected with an announcement in Klasse, i.e., the official magazine of the Flemish Ministry of Education that is sent to all teachers in Flanders. The teachers filled out the questionnaire via an anonymous online websurvey. Conducting an online survey has both disadvantages and benefits (see Wright 2005). In particular, the representativeness of the sample might be questionable as a result of self-selection. On the other hand, the validity of responses is greater in a web-based survey. Given the sensitivity of topics like Islamophobia, respondents are more likely to give socially desirable answers in a classic survey design compared to an anonymous web-based survey (see Kreuter, Presser, and Tourangeau 2008). A classic survey 
Table 1: Descriptive statistics for individual scale items measuring attitudes toward Muslim students

\begin{tabular}{lcc}
\hline Item & Mean & $S D$ \\
\hline $\begin{array}{l}\text { Muslim students reject jihad and violence } \\
\text { The Flemish Muslim students will integrate successfully } \\
\quad \text { into Flemish society }\end{array}$ & 2.17 & 1.99 \\
$\begin{array}{l}\text { Besides lessons in Catholicism, Catholic schools with } \\
\quad \text { Muslim students should also organize lessons in Islam }\end{array}$ & 2.15 & 1.61 \\
$\begin{array}{l}\text { Flanders should increase Muslim immigrant community to } \\
\quad \text { satisfy the labor shortage }\end{array}$ & 1.77 & 1.95 \\
$\begin{array}{l}\text { The majority of Muslim students have behavioral problems } \\
\quad \text { (reverse coded) }\end{array}$ & 4.06 & 1.65 \\
$\begin{array}{l}\text { Muslim immigrant students lack basic Dutch language } \\
\quad \text { skills (reverse coded) }\end{array}$ & 2.55 & 1.44 \\
$\begin{array}{l}\text { Many Muslim students look favorably on jihad (reverse } \\
\quad \text { coded) }\end{array}$ & 4.73 & 2.08 \\
$\begin{array}{l}\text { Wearing headscarves should be banned in all schools } \\
\quad \text { (reverse coded) }\end{array}$ & 3.05 & 2.15 \\
\hline
\end{tabular}

design might underestimate the degree of negative attitude. Social desirability response bias may occur even in a web survey.

The analyses are conducted using SPSS ${ }^{\odot} 19$. The number of missing values was very low for all variables except respondent's religion ( $<1.9$ percent). However, just over 6 percent $(6.61)$ of respondents did not provide their religious affiliation (see Table 2). Missing values for the religion variable are recoded as a dummy variable. Remaining missing values were handled using multiple imputation; six imputations were requested and pooled results are reported.

\section{Outcome Variable}

Teacher attitudes toward Muslim students are measured using eight items (see Table 1). Answer categories and their scores were as follows: (0) absolutely disagree, (1) disagree, (2) partly disagree, (3) neutral, (4) partly agree, (5) agree, and (6) totally agree. The scale yielded a Cronbach's alpha of .63.

\section{Independent Variables}

Teacher's religious background is assessed by self-identification. Thirty-five percent of the teachers identified themselves as Catholic, 17 percent as atheist, 17 percent as "religiously indifferent," 11 percent as Christian, 4 percent as agnostic, 4 percent as Muslim, 4 percent as "other," and 1 percent as Protestant. Seven percent of the responses were missing. Three categories (Catholic, Christian, and Protestant) were collapsed into one Christian category. Another three were collapsed into a nonreligious category (atheist, "religiously indifferent," and agnostic). A teacher's years of experience is used as a proxy for age. Educational level distinguishes between teachers who have a four-year university diploma and teachers with less than four years.

The variable school type distinguishes between teachers working in elementary schools, in secondary schools, and in adult education. Teachers were asked to estimate the percentage of Muslim students in their school. The variable school sector distinguishes between teachers working in privately run schools and in publicly run (state) schools. In Belgium, almost all privately run schools are Catholic schools and financial resources are the same for private and public schools (see Table 2 for descriptive statistics). 
Table 2: Descriptive statistics for variables: frequencies, range, means (for continuous variables) and percentages (for categorical variables) and standard deviations (SD)

\begin{tabular}{|c|c|c|c|c|c|}
\hline & $N$ & Min & $\operatorname{Max}$ & Mean or\% & $S D$ \\
\hline \multicolumn{6}{|l|}{ Gender } \\
\hline Male (ref) & 607 & 0 & 1 & $37.56 \%$ & \\
\hline Female & 607 & 0 & 1 & $62.44 \%$ & \\
\hline \multicolumn{6}{|l|}{ Religion } \\
\hline Christian (ref) & 620 & 0 & 1 & $47.10 \%$ & \\
\hline Muslim & 620 & 0 & 1 & $3.87 \%$ & \\
\hline Nonreligious & 620 & 0 & 1 & $38.23 \%$ & \\
\hline Other & 620 & 0 & 1 & $4.19 \%$ & \\
\hline Missing & 620 & 0 & 1 & $6.61 \%$ & \\
\hline \multicolumn{6}{|l|}{ Years of Experience } \\
\hline 0 to 4 (ref) & 611 & 0 & 1 & $14.73 \%$ & \\
\hline 5 to 9 & 611 & 0 & 1 & $22.09 \%$ & \\
\hline 10 to 14 & 611 & 0 & 1 & $15.22 \%$ & \\
\hline 15 to 19 & 611 & 0 & 1 & $12.93 \%$ & \\
\hline $20+$ & 611 & 0 & 1 & $35.02 \%$ & \\
\hline \multicolumn{6}{|l|}{ Educational Level } \\
\hline No university & 613 & 0 & 1 & $68.68 \%$ & \\
\hline University & 613 & 0 & 1 & $31.32 \%$ & \\
\hline \multicolumn{6}{|l|}{ School Type } \\
\hline Elementary (ref) & 607 & 0 & 1 & $33.61 \%$ & \\
\hline Secondary & 607 & 0 & 1 & $58.81 \%$ & \\
\hline Adult & 607 & 0 & 1 & $7.58 \%$ & \\
\hline \multicolumn{6}{|l|}{$\%$ Muslim Students } \\
\hline 0 to $9 \%$ (ref) & 613 & 0 & 1 & $36.54 \%$ & \\
\hline 10 to $29 \%$ & 613 & 0 & 1 & $23.16 \%$ & \\
\hline 30 to $49 \%$ & 613 & 0 & 1 & $11.42 \%$ & \\
\hline 50 to $69 \%$ & 613 & 0 & 1 & $9.79 \%$ & \\
\hline 70 to $100 \%$ & 613 & 0 & 1 & $19.09 \%$ & \\
\hline \multicolumn{6}{|l|}{ School Sector } \\
\hline Public-state run (ref) & 616 & 0 & 1 & $35.99 \%$ & \\
\hline Private run & 616 & 0 & 1 & $64.01 \%$ & \\
\hline \multicolumn{6}{|l|}{ Outcome Variable } \\
\hline Attitudes toward Muslim students & 615 & .083 & 5.630 & 3.018 & .906 \\
\hline
\end{tabular}

\section{RESULTS}

The multiple regression results are reported in Table 3. Gender is a significant determinant of teacher attitudes; female teachers hold more positive attitudes toward Muslim students than male teachers. Compared to Christians, Muslim teachers hold more positive attitudes as do teachers who report their religious background as "other." Nonreligious teachers do not significantly differ from Christian teachers. In additional analyses, when Muslim teachers are the reference category, nonreligious, "other," and respondents who did not report a religious affiliation (the missing values category) reported more negative attitudes toward Muslim students compared to Muslim teachers.

Years of experience as a teacher is also related to teacher attitudes. As years of experience increases, the effect size increases as well; teachers report more negative attitudes. Teachers with a university diploma report significantly more positive attitudes than those with less education. 
Table 3: Multiple regression analysis of teacher attitudes toward Muslim students: unstandardized coefficients (b), standard errors (se), and standardized coefficients $(\beta)$

\begin{tabular}{|c|c|c|c|}
\hline & $\mathrm{b}$ & $\mathrm{Se}$ & $\beta$ \\
\hline \multicolumn{4}{|l|}{ Gender } \\
\hline Female & .139 & .073 & .074 \\
\hline \multicolumn{4}{|l|}{ Religion $^{\mathrm{a}}$} \\
\hline Muslim & $1.620^{* * *}$ & .180 & .345 \\
\hline Nonreligious & .019 & .082 & .010 \\
\hline Other & $.620^{* * *}$ & .170 & .138 \\
\hline Missing & .125 & .139 & .034 \\
\hline \multicolumn{4}{|c|}{ Years of Experience } \\
\hline 5 to 9 & -.019 & .113 & -.009 \\
\hline 10 to 14 & -.124 & .121 & -.049 \\
\hline 15 to 19 & $-.263^{*}$ & .130 & -.100 \\
\hline $20+$ & $-.392^{* * *}$ & .108 & -.206 \\
\hline \multicolumn{4}{|c|}{ Educational Level } \\
\hline University & $.242^{* *}$ & .078 & .124 \\
\hline \multicolumn{4}{|l|}{ School Type } \\
\hline Secondary & $-.192^{*}$ & .077 & -.105 \\
\hline Adult & .197 & .141 & .061 \\
\hline \multicolumn{4}{|c|}{$\%$ Muslim Students } \\
\hline 10 to 29 & -.086 & .095 & -.040 \\
\hline 30 to 49 & -.092 & .123 & -.032 \\
\hline 50 to 69 & $-.325^{* *}$ & .125 & -.106 \\
\hline 70 to 100 & $-.316^{* *}$ & .103 & -.137 \\
\hline \multicolumn{4}{|l|}{ School Sector } \\
\hline Private & -.054 & .081 & -.029 \\
\hline Intercept & $3.188^{* * *}$ & .135 & \\
\hline
\end{tabular}

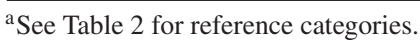

${ }^{* * *} p<.001,{ }^{* *} p<.01,{ }^{*} p<.05$.

Teachers working in secondary schools have more negative attitudes than elementary school teachers. But no statistical difference was found between adult education school teachers and elementary school teachers. The greater the percent of Muslims in a school, the more negative teacher attitudes are; when teachers perceive the share of Muslim students to be higher than 50 percent, they report more negative attitudes on average. Finally, school sector is not related to teachers' negative attitudes toward Muslim students.

\section{Discussion}

For decades researchers have emphasized the importance of teachers and their attitudes for equity and quality in education (Brophy 1983; Rosenthal and Jacobson 1968). With the increased number of Muslim citizens in Western countries, Islamophobia is also on the rise (see Sheridan 2006). However, attitudes of teachers toward Muslim students are rarely investigated. The aim of this study was to fill this research lacuna by examining the determinants of attitudes toward Muslim students.

Teacher attitudes are determined by both teacher and school characteristics. More specifically, regarding teacher characteristics, we find that female teachers, younger teachers, Muslim teachers, and teachers who hold a four-year college diploma hold more positive attitudes than male teachers, 
older teachers, Christian and nonreligious teachers, and teachers with a lower educational diploma. These findings are consistent with previous studies, which revealed that women hold less negative attitudes toward Muslims (see Bevelander and Otterbeck 2010; Heitmeyer and Zick 2004) and that negative attitudes are higher among less educated people (see Fetzer and Soper 2003; Heitmeyer and Zick 2004) and older respondents (Dunn, Klocker, and Salabay 2007; Heitmeyer and Zick 2004).

Teachers working in secondary schools have more negative attitudes toward Muslims than teachers in elementary schools. A potential explanation for this effect is the age group of the students served by the secondary school teachers. Secondary-school-aged immigrants are less integrated into society. The percentage of Muslim students in a school is also related to more negative teacher attitudes. This finding disconfirms intergroup contact theory (Allport 1954) and supports group threat theory (Blalock 1967). However, the percent of Muslim students in a school only affects teachers' attitudes when the concentration of Muslim students goes beyond a threshold of 50 percent.

Before discussing implications of these findings, it is important to review a few weaknesses in this study. First, because our research team opted to measure teachers' attitudes toward Muslim students with a specific focus on the educational context, we were not able to use more general psychometrically established instruments such as the New Measure of Anti-Arab Racism Scale (Echebarria-Echabe and Guede 2007) or the Islamophobia Scale (Lee et al. 2009). As a result, reliability may be low. Second, teachers were asked to estimate the percentage of Muslim students in their school. While previous Flemish studies have found that school staff are very accurate when asked to estimate the share of ethnic and religious minorities in their school (see Agirdag et al. 2011), teachers' attitudes might influence their perception about the percent of Muslim students in their school. Despite these limitations, the study reveals new information about an important topic. Hence, future research should incorporate the above-cited psychometrically established instruments and a direct measure of the share of Muslim students in a school.

This study has important policy implications. First of all, it is unacceptable that many Muslim students are confronted with teachers who hold negative attitudes toward them such as believing that Muslim students look favorably on violence and jihad. More disturbing is the fact that such attitudes are more prevalent among teachers who work in schools where greater numbers of Muslim students are enrolled. Policymakers might consider three strategies for changing this. First, school desegregation might be considered in order to change the religious composition of the schools and to create a social mix. However, such a reallocation policy should fundamentally differ from the early forced desegregation attempts in the United States, where black students were forcibly transferred to predominantly white schools. Such a policy has been shown to be fruitless and even detrimental to the educational achievement of ethnic minority students (Armor 1995). Therefore, if policymakers consider desegregation, voluntary enrollment of non-Muslim children in schools with a high percentage of Muslims should be proposed. Currently, the educational policy in Flanders encourages immigrant and less-educated parents to enroll their children in schools with a low percent of immigrant pupils and in schools where the students are more likely to have educated parents. Native Belgian and highly educated parents are encouraged to do just the opposite. However, parental organizations that strive toward voluntary desegregation are not structurally supported (see Agirdag and Van Houtte 2011). A second policy option is to provide more training to increase teachers' understanding of Islam and Muslim students. The results of this study indicate that non-Muslim teachers, secondary school teachers, and more experienced teachers may benefit from training in this area as well. ${ }^{1} \mathrm{~A}$ third option is to increase the number of Muslim teachers or teachers with a university diploma. Currently, only a very small portion of teachers in Flanders are immigrant Muslims. However, as our results indicate, Muslim teachers

\footnotetext{
${ }^{1}$ For a discussion of key factors for changing teachers' beliefs about religious diversity, see Garmon (2005).
} 
have more friendly attitudes toward Muslim students and as previous ethnographic studies point out, Muslim teachers might compensate for the lack of support students receive from non-Muslims teachers (Selby 1992; Zine 2008).

Finally, this study contributes to the study of religion and interreligious conflict. As previously mentioned, studies univocally emphasize the role of people's educational background for understanding the origins of their attitudes toward other people's religion. Nevertheless, within the contemporary framework of interreligious conflicts, experiences of students vis-à-vis the attitudes of teachers have received hardly any scholarly attention. Hence, this research note contributes to the understanding of the origins of interreligious tensions by focusing on the attitudes of teachers regarding the ever-growing Muslim population in Western schools.

\section{REFERENCES}

Abbas, Tahir. 2002. Teacher perceptions of South Asians in Birmingham schools and colleges. Oxford Review of Education 28(4):447-71

Agirdag, Orhan, Jannick Demanet, Mieke Van Houtte, and Piet Van Avermaet. 2011. Ethnic school composition and peer victimization: A focus on the interethnic school climate. International Journal of Intercultural Relations 35(4):465-73

Agirdag, Orhan, Maarten Hermans, and Mieke Van Houtte. 2011. De effecten van islamitische religie en religiositeit op de onderwijsprestaties [The effects of Islamic religion and religiosity on academic achievement]. Pedagogische Studiën 88(5):339-53.

Agirdag, Orhan and Mieke Van Houtte. 2011. A tale of two cities: Bridging families and schools. Educational Leadership 68(8):42-6.

Agirdag, Orhan, Mieke Van Houtte, and Piet Van Avermaet. 2011. Why does the ethnic and socio-economic composition of schools influence math achievement? The role of sense of futility and futility culture. European Sociological Review. DOI:10.1093/esr/jcq070 (published online).

Allport, Gordon W. 1954. The nature of prejudice. Cambridge, MA: Addison-Wesley.

Armor, David J. 1995. Forced justice: School desegregation and the law. New York: Oxford University Press.

Bevelander, Pieter and Jonas Otterbeck. 2010. Young people's attitudes towards Muslims in Sweden. Ethnic and Racial Studies 33(3):404-25.

Blalock, Hubert M. 1967. Toward a theory of minority-group relations. New York: Wiley.

Brophy, Jere E. 1983. Research on the self-fulfilling prophecy and teacher expectations. Journal of Educational Psychology 75(5):631-61.

Driessen, Geert. 2002. The effect of religious groups' dominance in classrooms on cognitive and noncognitive educational outcomes. International Journal of Education \& Religion 3(1):46-68.

Driessen, Geert and Frans Van derSlik. 2001. Religion, denomination, and education in the Netherlands: Cognitive and noncognitive outcomes after an era of secularization. Journal for the Scientific Study of Religion 40(4):561-72.

Dronkers, Jaap and Rolf van derVelden. 2010. Positive but also negative effects of ethnic diversity in schools on educational performance? An empirical test using cross-national PISA data (unpublished). Maastricht, The Netherlands: Maastricht University.

Dunn, Keven M., Natascha Klocker, and Tanya Salabay. 2007. Contemporary racism and Islamaphobia in Australia: Racializing religion. Ethnicities 7(4):564-89.

Echebarria-Echabe, Agustin and Emilia Fernández Guede. 2007. A new measure of anti-Arab prejudice: Reliability and validity evidence. Journal of Applied Social Psychology 37(5):1077-91.

Fetzer, Joel S. and J. Christopher Soper. 2003. The roots of public attitudes toward state accommodation of European Muslims' religious practices before and after September 11. Journal for the Scientific Study of Religion 42(2):24758.

Finn, Jeremy D. 1972. Expectations and the educational environment. Review of Educational Research 42(3):387-410.

Garmon, Arthur M. 2005. Six key factors for changing preservice teachers' attitudes/beliefs about diversity. Educational Studies 38(3):275-86.

Haque, Amber. 2001. Attitudes of high school students and teachers towards Muslims and Islam in a southeastern Australian community. Intercultural Education 12(2):185-96.

Heitmeyer, Wilhelm and Andreas Zick. 2004. Anti-semitism, Islamophobia and group-focused enmity in Germany. Bielefeld, Germany: Institute for Interdisciplinary Research on Conflict and Violence.

Hunter, Shireen T. (ed.). 2002. Islam, Europe's second religion: The new social, cultural, and political landscape. Westport, CT: Praeger.

Ipgrave, Julia, Joyce Miller, and Paul Hopkins. 2010. Responses of three Muslim majority primary schools in England to the Islamic faith of their pupils. Journal of International Migration and Integration 11(1):73-89. 
Kreuter, Frauke, Stanley Presser, and Roger Tourangeau. 2008. Social desirability bias in CATI, IVR, and web surveys: The effects of mode and question sensitivity. Public Opinion Quarterly 72(5):847-65.

Lee, Sherman A., Jeffrey A. Gibbons, John M. Thompson, and Hussam S. Timani. 2009. The Islamophobia scale: Instrument development and initial validation. International Journal for the Psychology of Religion 19(2):92-105.

Loobuyck, Patrick and Leni Franken. 2011. Religious education in Belgium: Historical overview and current debates. In Religious education in a plural, secularised society. A paradigm shift, edited by Leni Franken and Patrick Loobuyck, pp. 35-54. Münster: Waxmann.

McKown, Clark and Rhona S. Weinstein. 2008. Teacher expectations, classroom context, and the achievement gap. Journal of School Psychology 46(3):235-61.

Merry, Michael S. 2005. Social exclusion of Muslim youth in Flemish- and French-speaking Belgian schools. Comparative Education Review 49(1):1-23.

Niyozov, Sarfaroz and Gary Pluim. 2009. Teachers' perspectives on the education of Muslim students: A missing voice in Muslim education research. Curriculum Inquiry 39(5):637-77.

Norris, Pippa, and Ronald Inglehart. 2009. Cosmopolitan communications: Cultural diversity in a globalized world. New York: Cambridge University Press.

Richardson, Robin. 2004. Curriculum, ethos, and leadership: Confronting Islamophobia in UK education. In Confronting Islamophobia in educational practice, edited by Barry van Driel, pp. 19-34. Staffordshire, UK: Trentham.

Rosenthal, Robert and Lenore Jacobson. 1968. Pygmalion in the classroom: Teacher expectation and pupils' intellectual development. New York: Holt.

Savelkoul, Michael, Peer Scheepers, Jochem Tolsma, and Louk Hagendoorn. 2010. Anti-Muslim attitudes in the Netherlands: Tests of contradictory hypotheses derived from ethnic competition theory and intergroup contact theory. European Sociological Review. DOI: 10.1093/esr/jcq035 (published online).

Schinkel, Willem and Friso van Houdt. 2010. The double helix of cultural assimilationism and neo-liberalism: Citizenship in contemporary governmentality. British Journal of Sociology 61(4):696-715.

Selby, Karen. 1992. The Islamic schooling movement in the United States: Teacher's experiences in one full-time Islamic school. Muslim Education Quarterly 9(1):35-48.

Sharpes, Donald K., Lotte Rahbek Schou, Iouri Zagoumennov, Geir Karlsen, Ove Haugalokken, and Stefan Hopmann. 2010. Teacher attitudes toward Muslim students integration into civil society. In Handbook on international studies in education, edited by Donald K. Sharpes, pp. 141-53. Charlotte, NC: Information Age Publishing.

Sheridan, Lorraine P. 2006. Islamophobia pre- and post-September 11th, 2001. Journal of Interpersonal Violence 21(3):317-36.

Tajfel, Henri. 1981. Human groups and social categories. Cambridge, UK: Cambridge University Press

Van den Bergh, Linda, Eddie Denessen, Lisette Hornstra, Marinus Voeten, and Rob W. Holland. 2010. The implicit prejudiced attitudes of teachers: Relations to teacher expectations and the ethnic achievement gap. American Educational Research Journal 47(2):497-527

Van Houtte, Mieke. 2011. So where's the teacher in school effects research?: The impact of teacher's beliefs, culture, and behavior on equity and excellence in education. In Equity and excellence in education: Towards maximal learning opportunities for all students, edited by Kris Van den Branden, Piet Van Avermaet, and Mieke Van Houtte, pp. 75-95. New York: Routledge.

Wright, Kevin B. 2005. Researching Internet-based populations: Advantages and disadvantages of online survey research, online questionnaire authoring software packages, and web survey services. Journal of Computer-Mediated Communication 10(3):Article 11.

Zine, Jasmin. 2001. Muslim youth in Canadian schools: Education and the politics of religious identity. Anthropology \& Education Quarterly 32(4):399-423.

- 2008. Canadian Islamic schools: Unraveling the politics of faith, gender, knowledge, and identity. Toronto, Canada: University of Toronto Press. 